\title{
Causes of accidents and benefit of safety to local masons in Wukari, Nigeria
}

\author{
Ogodor Elvis Ikechukwu
}

Civil Engineering Department, Near East University, Nicosia, Mersin 10, Turkey

\section{ARTICLE INFO}

\section{ARTICLE HISTORY:}

Received: 25 May 2020

Revised: 10 July 2020

Accepted: 27 July 2020

Published: 28 July 2020

\section{KEYWORDS:}

Masons, contractor

horseplay, four-point ranking, accidents

\author{
A B S T R A C T
}

The objective of this research is to ascertain the causes of accidents to native construction workers (masons) in Wukari, Nigeria and to enumerate the benefits of such safety practices. Forty questionnaires were carefully analysed using a four-point ranking strategy that is predicated on a mid-rank method. According to this research, shortages and lack of equipment have been the major causes of construction accidents. Masons climb ladders without even wearing their tops, boots or helmet. In fact, they are proud of this madness. Moreover, horseplay and lack of training have also significantly contributed to the accident cases. The major benefit of safety is that it raises the professional image of the construction workers and the contractor that employed them. This increases their chances of getting more projects. Government and well-meaning leaders in Taraba state are advised to enforce safety measures on the stubborn construction workers in Wukari.

\section{INTRODUCTION}

According to the International Training Centre of the International Labour Organization, one in six fatal accidents at work occurs at construction sites. It also states that no more than 60,000 fatal accidents occur on construction sites around the world on an annual basis (ITC, 2011). Building work is a hazardous profession and is typically full of hazards, for example, exposure to unsafe substances such as paint, glues and asbestos, drilling that can cause explosions and fires, the possibility of debris falling, workers falling from heights, motor vehicle collisions, construction accidents, electrocution and structural collapse (Belel \& Mahmud, 2012). Safety considerations in the delivery of construction projects are not given priority in most developing countries like Nigeria, and the employment of safety measures during construction is considered a burden (Mbuya \& Lema, 1996). Many construction workers blame their site accidents on bad luck. This is a misconception due to the lack of awareness of safety practices on construction sites. Many accidents can be prevented simply by taking measures such as the practice of safety, including good housekeeping of construction sites, the provision of safety training for workers and the proper use of personal protective equipment (Onoyan-usina et al., 2019). Safety regulations normally do not exist in developing countries; if any, the regulatory authority is typically very weak when applying certain regulations effectively. Furthermore, work risks at the construction site are either not considered at all or considered to be less dangerous than they are. Building activities in developing countries are labour-intensive in regards to construction (Belel \& Mahmud, 2012).

Safety culture includes a set of beliefs, attitudes, norms, roles, social and technical practices concerned with minimizing the exposure of employees, managers, customers and members of the public to conditions that are considered hazardous or injurious (Diaz-Cabrera et al., 2007). The issue with developing countries is that the laws intended to protect workers from accidents at construction sites cannot be strictly enforced by contractors. Furthermore, workers themselves tend to ignore basic safety rules and regulations intended to protect and prevent them from becoming involved in accidents, according to (Singh et al., 1999). It is important to note that the culture of an organization evolves over a period of time and cannot be generated immediately. The safety culture of an organization evolves as a result of its history, work 
climate, labour force, health and safety policies, and management leadership (Reason, 1998).

The problems faced are not limited to a single country, as they spread through nearly all countries in the construction sector. Such issues tend to be more severe in less developed countries than in more developed richer nations. The construction industry in developed countries has performed well below expectations in the area of health. The situation in Nigeria is even worse than in other countries (Godwin, 2011). There is no reliable data on construction accidents in Nigeria. This is because most contractors fail to report cases of accidents to the ministerial departments in charge of such occurrences, as they do not keep proper records themselves (Okeola, 2009).

A number of obstacles hinder the output of the construction industry in Nigeria. This includes a lack of skilled labour, shortage of materials, power cuts, etc. (Dantata, 2007). Despite the introduction of mechanization in the building industry and technical progress, most sites still have about 50 per cent manual labour being used in these processes (Okeola, 2009). Perhaps this high rate of manual employment plays a significant role in the high accident rates reported among workers in the construction industry. Benefits of practising an effective safety culture include reduced accidents at the site, reduced injuries, fatalities, sick pay, loss of work hours, claims for compensation, absenteeism, agitation of workers and overall project costs, moreover, improvement in efficiency and profitability (Enhassi et al., 2008).

Wukari is the headquarters of the Wukari local government area of Taraba State, Nigeria. It has an area of 4,308 square kilometres, with a latitude of 7,89N and a longitude of 9,77E (Okrikata \& Yusuf, 2016). Wukari is situated in the southern part of Taraba State, geographically in the northern Guinea-Savannah vegetation belt and has an annual rainfall of about 150-200 $\mathrm{mm}$ with an average temperature of $18^{\circ} \mathrm{C}$ and a maximum temperature of $38^{\circ} \mathrm{C}$ (Shitta et al., 2017). The reason for choosing this town was due to the interesting facts about its location and the level of exposure of those living there. Taraba state in its entirety is a state that is far and secluded from the Nigerian civilization. In fact, $40 \%$ of its towns are without electricity. Though Wukari has electricity, the natives in Wukari are known for building without plans or care. Ancestrally they were warriors (Jukuns), so they pay less attention to safety measures as they look to themselves as being supermen. This mindset has become a social and occupational protocol such that safety rules usually do not exist, plus, the regulatory authority is usually very weak. Hazards at the construction workplace are either not perceived at all, or perceived to be less dangerous in Wukari. Our focus will be on the local masons (native construction workers). The objective of this research is to estimate the extent of negligence and carelessness of native masons in Wukari. To ascertain the causes of accidents to these native workers, to determine what precautionary safety methods they locally apply and ultimately identify the benefits of such safety practices.

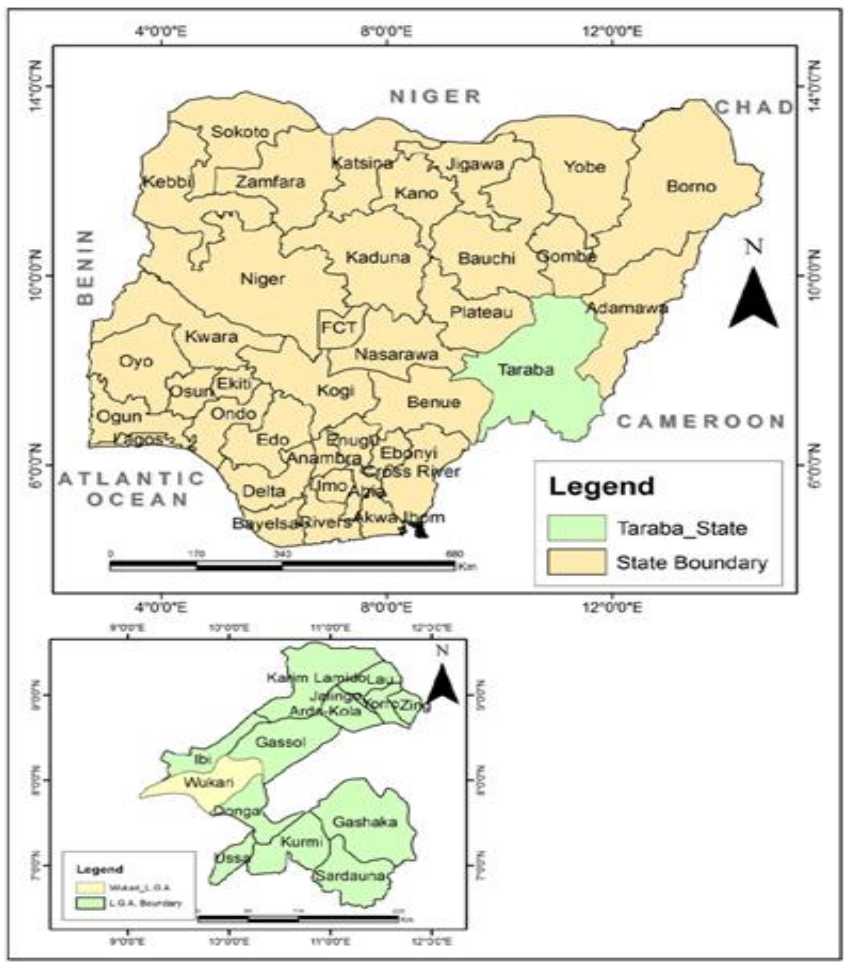

Fig.1. Google map showing Wukari, Taraba State, Nigeria

(Google maps, 2015)

\section{METHODOLOGY}

This research focuses on small construction companies and how native masons practice their construction work. Forty-five questionnaires were distributed, out of the distributed questionnaires only forty-one were submitted, out of which one was not filled completely. So we will work with only forty well-answered questionnaires. It took great effort, a lot of persuasion and strength to make these local masons answer the questionnaires. This may be due to the superstition that discourages discussing accidents, so we had to keep the questionnaire brief and straight to the point. The analysis of questionnaires was carried out using a four-point ranking to measure a range of opinions, from the least important to the most important. The total score was obtained by multiplying the number of respondents by the corresponding score mark and adding the results together. Mean of each factor equals the total score/ sample size Relative Index (R.I.) equals the total score/highest score mark $\mathrm{x}$ sample size. Where ties occurred, the mid-rank method was used to resolve the problem (Belel \& Mahmud, 2012). Data collection was done between the $2^{\text {nd }}$ to $22^{\text {nd }}$ of February 2020. This period was before the first case of COVID-19 was discovered in 
Nigeria. The discovery subsequently led to lockdown in Nigeria. The number of correctly completed questionnaires was forty. The data collected from the questionnaires were presented in tabular form and analysed.

\subsection{Questionnaire}

This research is designed to help us know the challenges and risk you are facing at work and to see how both the government and the general public can be of assistance.

Table 1. Personal details

\begin{tabular}{|l|l|l|l|l|}
\hline Questions & \multicolumn{3}{|l|}{ Answers } \\
\hline 1. How old are you? & \multicolumn{3}{|l|}{} \\
\hline $\begin{array}{l}\text { 2. For how many years have you } \\
\text { been involved in construction? }\end{array}$ & $\begin{array}{l}6-10 \\
\text { years }\end{array}$ & $\begin{array}{l}11-15 \\
\text { years }\end{array}$ & $\begin{array}{l}16-20 \\
\text { years }\end{array}$ & $\begin{array}{l}\text { Over } \\
25 \\
\text { years }\end{array}$ \\
\hline $\begin{array}{l}\text { 3. Have you ever had a work- } \\
\text { related accident before? }\end{array}$ & Yes & No \\
\hline $\begin{array}{l}\text { 4. If yes, when and how (short } \\
\text { answer)? }\end{array}$ & & \\
\hline $\begin{array}{l}\text { 5. Have you ever received any } \\
\text { formal training, or have you } \\
\text { attended a workshop on safety and } \\
\text { Healthy practices in construction? }\end{array}$ & & \\
\hline
\end{tabular}

Table 2. The main cause of accidents

\begin{tabular}{|l|l|l|l|l|}
\hline 6. What was the main cause of site accident? \\
\hline Variables & $\begin{array}{l}\text { Partially } \\
\text { disagree (1) }\end{array}$ & $\begin{array}{l}\text { Partially } \\
\text { agree (2) }\end{array}$ & $\begin{array}{l}\text { Agree } \\
\text { (3) }\end{array}$ & $\begin{array}{l}\text { Strongly } \\
\text { agree (4) }\end{array}$ \\
\hline Lack of training & & & & \\
\hline Carelessness & & & & \\
\hline Unsafe behaviour & & & & \\
\hline Overconfidence & & & & \\
\hline $\begin{array}{l}\text { Poor work } \\
\text { understanding }\end{array}$ & & & & \\
\hline Equipment shortage & & & & \\
\hline
\end{tabular}

Table 3. Benefits of safety

\begin{tabular}{|l|l|l|l|l|}
\hline \multicolumn{7}{|l|}{ 7. What are the known benefits of safety? } \\
\hline variables & $\begin{array}{l}\text { Partially } \\
\text { disagree (1) }\end{array}$ & $\begin{array}{l}\text { Partially } \\
\text { agree (2) }\end{array}$ & $\begin{array}{l}\text { Agree } \\
(3)\end{array}$ & $\begin{array}{l}\text { Strongly } \\
\text { agree (4) }\end{array}$ \\
\hline $\begin{array}{l}\text { Reduced accident } \\
\text { cost }\end{array}$ & & & & \\
\hline $\begin{array}{l}\text { Increased } \\
\text { productivity }\end{array}$ & & & & \\
\hline $\begin{array}{l}\text { Improved human } \\
\text { relations }\end{array}$ & & & & \\
\hline $\begin{array}{l}\text { Raise the } \\
\text { professional image }\end{array}$ & & & & \\
\hline
\end{tabular}

\section{RESULTS AND DISCUSSIONS}

\subsection{Age distribution of respondents}

Five out of the forty $(12.5 \%)$ workers that responded to the questionnaires were over 50 years of age, twelve $(30 \%)$ fall within 41-50 years, fourteen (35\%) fall within 31-40 years. Finally, nine $(22.5 \%)$ of the responding workers are between 21-30 years. The quality of work displayed by the older workers shows a lot of maturity and experience than the younger ones. A more presentable display of the age distribution can be seen in Table 4 .

Table 4. Age distribution

\begin{tabular}{|l|l|l|}
\hline Age & Respondent & Percentage \\
\hline $21-30$ & 9 & $22.5 \%$ \\
\hline $31-40$ & 14 & $35 \%$ \\
\hline $41-50$ & 12 & $30 \%$ \\
\hline Above 50 & 5 & $12.5 \%$ \\
\hline Total & 40 & $100 \%$ \\
\hline
\end{tabular}

Taking a closer look at the age distribution of our respondent from Table 4 . It can be realized that most of these local construction workers (masons) are between the ages of $31-40$, and as expected, it is only $12.5 \%$ of them that are above fifty in age. It should not be expected that a person above fifty to have the strength of thirty and below. As this result is compared with the work of Belel and Mahmud (2010). It can be realized that the highest number of respondents were between 41-50 years, while $9.5 \%$ of them are over 50 years of age. The degree of manual labour which involves little or no mechanization is the daily challenge of a local construction worker, that is why local construction work is not good for a man above 50 years of age. This makes them look weary and older than their age.

\subsection{Years of experience}

Table 5. Years of experience

\begin{tabular}{|l|c|c|}
\hline Years of experience & Respondent & Percentage \\
\hline $0-5$ & 5 & $12.5 \%$ \\
\hline $6-10$ & 11 & $27.5 \%$ \\
\hline $11-15$ & 13 & $32.5 \%$ \\
\hline $16-20$ & 5 & $12.5 \%$ \\
\hline 25 and above & 6 & $15.0 \%$ \\
\hline Total & 40 & $100.0 \%$ \\
\hline
\end{tabular}

Most of the respondents in Table 5 have 11-15 years of work experience. In contrast, $15 \%$ of the respondents have the highest years of experience. We should note that their years of experience does not make them more qualified. In 2014, Hickson and Ellis (2014) discovered that there are seven specific concerns that poorly qualified construction employees have despite their years of experience. They are inventory and machinery supply delays, defective plant and equipment shortages, insufficient supervision, unnecessary rework, lack of benefits, lack of enthusiasm and an inefficient work scheduling (Hickson \& Ellis, 2014). As shown in Fig. 2, 12.5\% of respondent have up to five years of experience. This is graphically expressed with the blue bar between the y-axis respondent value, 4 to 6 . The mode, which is the highest bar, is represented between the respondent value 12 to 14 . This is the reading for those that have 11 to 15 years of experience. Showing that the highest number of respondents used for this research have between 11 to 15 years of experience. 


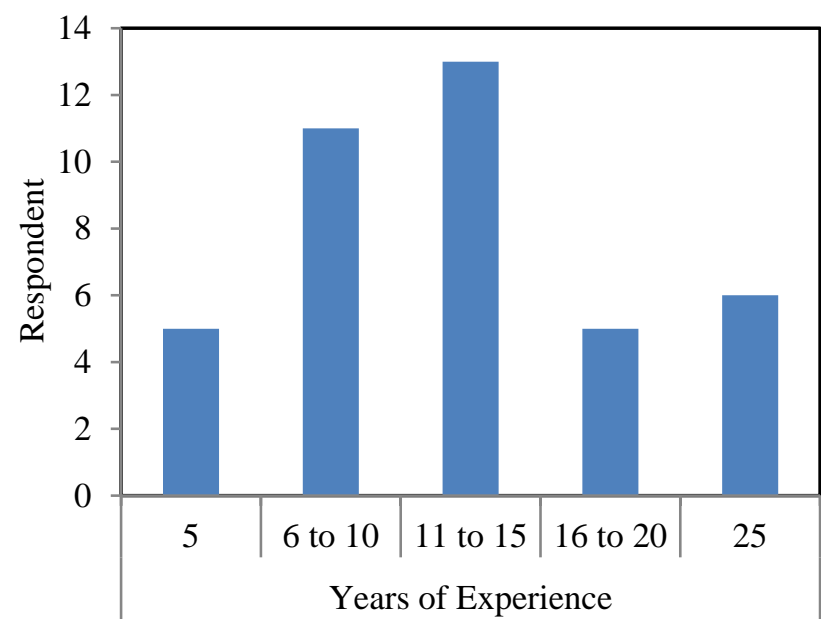

Fig. 2. Years of experience of the respondents

\subsection{Accident cases}

Out of 40 respondents, $21(52.5 \%)$ admitted being involved in accidents during construction while the rest said they never had. Though 15 (37.5\%) claimed they had had a near-miss accident. All confirmed that there were no formal reports made for the accidents or no efforts to compensate workers except if the accident is fatal. No form of a safety program is available to the native masons, furthermore no training on safety, except training on construction, which most learn on the job. Local construction workers added to the responses that they were never trained professionally. It is just the matter to come to a construction site regularly, assist with any given task possible, and after some weeks the person will be will become part of the construction group.

\subsection{Main causes of accidents on site}

Table 6. Ranking of causes of accidents on site

\begin{tabular}{|l|l|l|l|l|l|l|l|l|}
\hline \multicolumn{10}{|c|}{ Responses/score } \\
\hline Variables & $\mathbf{1}$ & $\mathbf{2}$ & $\mathbf{3}$ & $\mathbf{4}$ & $\mathbf{T o t a l}$ & Mean & R.I. & Rank \\
\hline $\begin{array}{l}\text { Lack of } \\
\text { training }\end{array}$ & 9 & 3 & 5 & 23 & 122 & 3.05 & 0.76 & 3 \\
\hline Carelessness & 12 & 3 & 20 & 5 & 98 & 2.45 & 0.61 & 5 \\
\hline $\begin{array}{l}\text { Unsafe } \\
\text { behaviour }\end{array}$ & 6 & 5 & 7 & 22 & 125 & 3.13 & 0.78 & 2 \\
\hline $\begin{array}{l}\text { Over } \\
\text { confidence }\end{array}$ & 21 & 9 & 3 & 7 & 76 & 1.9 & 0.48 & 6 \\
\hline $\begin{array}{l}\text { Poor } \\
\text { understanding } \\
\text { of the risk } \\
\text { associated with } \\
\text { work }\end{array}$ & 9 & 7 & 6 & 18 & 113 & 2.83 & 0.70 & 4 \\
\hline $\begin{array}{l}\text { Equipment } \\
\text { shortage }\end{array}$ & 5 & 5 & 5 & 25 & 130 & 3.25 & 0.81 & 1 \\
\hline
\end{tabular}

Shortage of equipment in Table 6 was considered the highest cause of accidents on site. This is followed by unsafe behaviour, then lack of training, especially training designed to teach workers how to be safety conscious. The Fourth cause is the poor understanding of the risk associated with work; the fifth reason is carelessness while the least insignificant cause of accidents on site is overconfidence.

\subsection{Benefits of safety}

Table 7. Ranking of benefits of safety on site

\begin{tabular}{|l|l|l|l|l|l|l|l|l|}
\hline \multicolumn{10}{|c|}{ Responses/Score } \\
\hline Variables & $\mathbf{1}$ & $\mathbf{2}$ & $\mathbf{3}$ & $\mathbf{4}$ & Total & Mean & R.I. & Rank \\
\hline $\begin{array}{l}\text { Reduced } \\
\text { accident costs }\end{array}$ & 20 & 3 & 4 & 13 & 90 & 2.25 & 0.56 & 4 \\
\hline $\begin{array}{l}\text { Increased } \\
\text { productivity }\end{array}$ & 9 & 1 & 5 & 25 & 126 & 3.15 & 0.79 & 3 \\
\hline $\begin{array}{l}\text { Improved } \\
\text { human } \\
\text { relations }\end{array}$ & 5 & 7 & 2 & 26 & 129 & 3.23 & 0.81 & 2 \\
\hline $\begin{array}{l}\text { Raise } \\
\text { professional } \\
\text { image }\end{array}$ & 3 & 8 & 3 & 26 & 132 & 3.3 & 0.83 & 1 \\
\hline
\end{tabular}

According to Table 7 , the raise of the professional image is the highest benefit of safety. Followed by improves human relations, then increase productivity before finally reducing accident cost.

\section{CONCLUSIONS}

It is so appalling that among the native construction workers (masons) interviewed and those that did not even fill the questionnaires, none has been trained about safety. Moreover, there is no provision for reporting the accident cases. There is no form of records for accident cases and victims. No one has even thought about keeping cases of accidents for the purpose of the reference to prevent a similar occurrence. Only $52.5 \%$ of the respondents admitted being involved in accidents during construction. In Wukari they have been infamously known for their carelessness. This result expresses similarities with the previous statement of Okeola (2009). There are no reliable data on construction accidents in Nigeria (Okeola, 2009). Shortages and lack of equipment have been the major cause of construction accident according to this research. This is potentially accurate because local masons in Wukari are frequently seen working on buildings, climbing ladders without even wearing their shirts, boots or helmets. They regard this stupidity as strength. Horseplay and lack of training have also significantly contributed to the accident cases in this research. This is also in agreement with the earlier discovery of Dantata (2007). Who said that lack of skilled labour, shortage of materials and power cuts are the causes of site accident (Dantata, 2007). In cases where safety is applied, the respondents believe that safety raises the professional image of the construction workers and the contractor that employed them. Professional image and improved humans relations mean that the relationship between the worker, the contractor, the owner of the contract and the general public will be smooth if work is done carefully and neatly. This will increase their publicity 
and their opportunity to get more contracts. The local government, youth leaders, traditional leaders and the society at large in Wukari should initiate the change of educating and encouraging their youths to apply safety rules. As the construction workers endangered their lives on a daily basis, this behaviour shall be changed. It can progressively start by having a comprehensive record of construction-based accidents, then enforcing laws that will are safety-sensitive. Gradually enhancing the culture of safety awareness for individuals and companies. Prevention is better than cure!

\section{CONFLICT OF INTEREST STATEMENT}

The author declares that there is no conflict of interest.

\section{REFERENCES}

[1] Onoyan-usina, A., Baba, Y. A., Yakubu, K., \& Ibrahim, S. (2019). Safety practices of Nigerian construction site workers: A Case Study of Benin-City and Gombe Metropolis. Scientific Research Journal, 7(2), 29-42.

[2] Belel, Z. A., \& Mahmud, H. (2012). Safety culture of Nigerian construction workers - A case study of Yola. International Journal of Scientific \& Engineering Research, 3(9), 870-874.

[3] Dantata, S. (2007). General overview of the Nigerian construction industry [Doctoral Dissertation, Massachusetts Institute of Technology]. MIT Libraries. https://dspace.mit.edu/handle/1721.1/44272

[4] Diaz-Cabrera. D., Hernández-Fernaud. E., Isla-Díaz. R. (2007). Evaluation of a new instrument to measure organizational safety culture values and practices. Accid. Anal. Prev. 39(6), 1202-1211.

[5] Enhassi, A., Choudhry, R. M., Mayer, P. E., \& Shoman, Y. (2008). Safety Performance of Subcontractors in the Palestinian Construction Industry. Journal of Construction in Developing Countries, 13(1), 51-62.

[6] Godwin, I. (2011). Effect of Mechanization on occupational health and safety performance in the Nigerian construction industry. Journal of construction in developing countries, 16(2), 27-45.

[7] Mbuya, E., \& Lema, N. M. (1996). Towards development of a framework for integration of safety and quality management techniques in construction project delivery process. International Journal of Quality, 14(5), 1-15.

[8] Okeola, O. G. (2009). Occupational Health and Safety (OHS) assessment in the construction industry. 1st annual civil engineering conference. Physical Planning Unit, University of Ilorin, Nigeria.

[9] Okrikata, E., \& Yusuf, O. A. (2016). Diversity and abundance of insects in Wukari, Taraba State, Nigeria. International Biological and Biomedical Journal, 2(4), 156-166.

[10] Reason, J. (1998). Achieving a safe culture: Theory and practice. Work and stress, 12(3), 293-306.

[11] Shitta, K. B., James-Rugu, N. N., Chessed, G., \& Ngwamah, J. S. (2017). Ectoparasites of chickens in Wukari Local Government Area of Taraba State, North-East Nigeria. Nigerian Journal of Parasitology, 38(1), 39-42.

[12] Singh, A., Hinze, J., \& Coble, R. J. (1999). Implementation of safety and health on construction sites - Proceedings of the Second International Conference of CIB Working Commission W99, Honolulu, Hawaii, 427-434.

[13] ITC "The International Training Centre of ILO" (2011). Occupational safety and health management in the construction sector. Retrieved from http://socialprotection.itcilo.org/en/courses/Open_cour ses/A904155

[14] Hickson, B. G., \& Ellis, L. A. (2014). Factors affecting construction labour productivity in Trinidad and Tobago. The Journal of the Association of Professional engineers of Trinidad and Tobago, 42(1), 4-11. 